\title{
PELATIHAN DAN PENDAMPINGAN KIAT MENINGKATKAN OMZET PENJUALAN DAN PENCATATAN TRANSAKSI KEUANGAN PADA KOPERASI TOKO KELONTONG RUNGKUT SURABAYA
}

\author{
TRAINING AND MENTORING TIPS TO INCREASE SALES TURNOVER AND \\ RECORDING FINANCIAL TRANSACTIONS AT THE RUNGKUT GROCERY \\ STORE COOPERATIVE IN SURABAYA
}

\author{
Wininatin Khamimah*, Tegowati, Nenny Syahrenny, In'am Widiarma \\ Sekolah Tinggi Ilmu Ekonomi Indonesia (STIESIA) Surabaya \\ Jln. Menur Pumpungan No. 30 Surabaya \\ *Email: wininatinkhamimah@stiesia.ac.id \\ (Diterima 25-02-2021; Disetujui 19-03-2021)
}

\begin{abstract}
ABSTRAK
Konsep koperasi toko kelontong ini mempunyai potensi yang luar biasa dan memberikan dampak ekonomi yang luas bagi masyarakat di Kota Surabaya. Untuk itulah Pemerintah Kota Surabaya memberikan dukungan maksimal agar koperasi toko kelontong dapat dikembangkan dengan baik. Namun, selama masa Pandemi Covid19 usaha toko kelontong mengalami penurunan omzet penjualan karena berbaga faktor. Pendapatan masyarakat yang menurun dan jumlah mini market yang masuk perkampungan makin banyak menjadi beberapa faktor penyebabnya. Masalah lain yang dihadapi dalam menjalankan usahanya adalah belum melakukan pencatatan transaksi keuangan. Berdasarkan masalah di atas, maka dilakukan kegiatan pengabdian kepada masyarakat ini dengan tujuan: a) Memberi pelatihan (secara offline) mengenai kiat meningkatkan omzet penjualan toko kelontong di era new normal dan pencatatan transaksi keuangan; b) Melakukan pendampingan (secara online) mengenai kiat meningkatkan omzet penjualan toko kelontong di era new normal, dan pencatatan transaksi keuangan pada Koperasi Toko Kelontong Kecamatan Rungkut Kota Surabaya. Metode pelaksanaannya dengan cara: 1.) Survey lokasi di Kecamatan Rungkut dan Koperasi Toko Kelontong. 2) Mengidentifikasi permasalahan yang dihadapi anggota koperasi toko kelontong. 3) Melakukan pelatihan (secara offline/tatap muka) sesuai permasalahan yang ada. 4) Melakukan pendampingan (secara online melalui whatsapp group dan video call). Kegiatan pengabdian kepada masyarakat bagi anggota koperasi ini telah berjalan dengan baik dan sesuai rencana. Kegiatan ini memberikan manfaat bagi para anggota koperasi toko kelontong utamanya dalam penerapan kiat-kiat meningkatkan omzet penjualan di era new normal dan pencatatan transaksi keuangan.
\end{abstract}

Kata Kunci: Koperasi Toko Kelontong; Omzet Penjualan; Pencatatan Transaksi Keuangan

\begin{abstract}
The concept of this grocery store cooperative has tremendous potential and has a broad economic impact on the community in the city of Surabaya. For this reason, the Surabaya City Government provides maximum support. However, during the Covid19 Pandemic, the grocery store business experienced a decline in sales turnover due to various factors. The decreasing income of the people and the number of mini markets that have entered the residence are some of the factors causing it. Another problem is not recording financial transactions. Based on the problems, this community service activity was carried out with the aim of: a) Providing training on tips to increase grocery store sales turnover in the new normal era and recording financial transactions; b) Provide assistance regarding tips on increasing grocery store sales turnover in the new normal era and recording financial transactions at the Grocery Store Cooperative, Rungkut District, Surabaya. The method of implementation is: 1.) Surveying the location in the Rungkut District and the Grocery Store Cooperative. 2) Identifying problems faced by members of the grocery store cooperative. 3) Conduct training (offlinelface-to-face) according to existing problems. 4) Provide assistance (online via whatsapp group and video call). Community service activities for cooperative members have gone well and according to plan. This activity provides benefits for members of the grocery store cooperative, especially in implementing tips to increase sales turnover in the new normal era and recording financial transactions.
\end{abstract}

Keywords: Grocery Store Cooperative, Sales Turnover, Recording of Financial Transactions 
Pelatihan dan Pendampingan Kiat Meningkatkan Omzet Penjualan dan Pencatatan Transaksi Keuangan Pada Koperasi

\section{PENDAHULUAN}

Toko kelontong atau toko serba ada (convenience store/grocery sore) adalah toko kecil yang mudah diakses dan bersifat lokal. Toko semacam ini umumnya di pinggir jalan yang ramai, stasiun pengisian bahan bakar (SPBU) atau stasiun kereta api. Toko kelontong juga tersebar di perumahan padat perkotaan hingga pedesaan. Kebanyakan toko kelontong masih bersifat konvensional. Pembeli tidak bisa mengambil sendiri barang-barang yang dibutuhkan, ada rak pembatas antara penjual dan pembeli. Sejak 2018 toko kelontong dijadikan salah satu pilihan bentuk unit usaha koperasi yang digalakkan Pemkot Surabaya agar keuntungan yang diperoleh kembali lagi untuk kesejahteraan warga (Wininatin, 2020).

Unit usaha toko kelontong dipilih karena lebih dekat dengan kebutuhan masyarakat. Perputaran uang pun relatif cepat sehingga bisa mendukung perekonomian di tingkat kota, maka pemkot ingin mengembangkan koperasi ini. Hal ini karena koperasi merupakan badan hukum yang bisa dipakai untuk kerja sama dengan distributor. (https;//dinkopum.surabaya.go.id). Kepala Dinas Perdagangan Kota Surabaya Wiwiek Widayati mengatakan bahwa pemkot terus membina koperasi toko kelontong. Hingga Pebruari 2021, pendampingan telah dilakukan pada 885 koperasi toko kelontong yang tersebar di 31 kecamatan di Surabaya (https;//republika.co.id).

Pandemi COVID-19 yang dialami Indonesia sejak 16 Maret 2020 berpengaruh pada usaha toko kelontong. Usaha ini mengalami penurunan omzet penjualan karena berbagai faktor. Pendapatan masyarakat yang menurun dan jumlah mini market yang masuk perkampungan makin banyak menjadi beberapa faktor penyebabnya.

Omzet penjualan adalah akumulasi kegiatan penjualan produk barang dan jasa yang dihitung secara keseluruhan selama kurun waktu tertentu secara terus menerus atau dalam satu proses akuntansi. Omzet penjualan dari tahun ke tahun tidak selalu sama. Swastha (2005) dalam Rizal (2017) mengemukakan bahwa faktor-faktor yang mempengaruhi besar kecilnya omzet dibagi menjadi dua yaitu:

(1) Faktor internal (faktor yang dikendalikan oleh pihak-pihak perusahaan), diantaranya: kemampuan perusahaan untuk mengelola produk yang akan dipasarkan, kebijaksanaan harga, dan promosi yang digariskan perusahaan, serta kebijaksanaan untuk memilih perantara yang digunakan.

(2) Faktor eksternal (faktor yang tidak dapat dikendalikan oleh pihak perusahaan), diantaranya: perkembangan ekonomi dan perdagangan baik nasional maupun 
internasional, kebijakan pemerintah di bidang ekonomi, perdagangan dan moneter, dan suasana persaingan pasar.

Masalah lain yang dihadapi anggota koperasi dalam menjalankan usahanya adalah belum mampu melakukan pencatatan transaksi keuangan. Pencatatan transaksi keuangan atau secara sederhana disebut pembukuan sangat penting dalam dunia usaha. Pembukuan biasanya mencatat peristiwa-peristiwa ekonomi, maka pembukuan merupakan satu bagian proses akuntansi. Sedangkan akuntansi melibatkan keseluruhan proses pengidentifikasian, pencatatan dan pengomunikasian peristiwa-peristiwa ekonomi (Andarsari, 2018). Penerapan akuntansi usaha kecil terkendala faktor pendidikan yang rendah dalam hal pengetahuan akuntansi dan kurangnya kesadaran pentingnya akuntansi. Beberapa penelitian menunjukkan bahwa praktek akuntansi usaha kecil di Indonesia belum berjalan baik. Penelitian lain menunjukkan bahwa kebutuhan terhadap penerapan akuntansi masih rendah dan banyak responden yang belum pernah mengikuti pelatihan akuntansi (Rais, 2019).

Berdasarkan masalah di atas, maka dilakukan kegiatan pengabdian kepada masyarakat ini dengan tujuan:

a. Memberi pelatihan kiat meningkatkan omzet penjualan toko kelontong dan pencatatan transaksi keuangan (secara offline).

b. Melakukan pendampingan kiat meningkatkan omzet penjualan toko kelontong dan pencatatan transaksi keuangan (secara online).

\section{BAHAN DAN METODE}

Bentuk kegiatan pengabdian dilakukan dengan dua cara, yaitu offline dan online. Kegiatan pelatihan dilakukan secara offline (tatap muka langsung) dengan para anggota Selanjutnya dilakukan pendampingan secara online (daring melalui grup whatsapp dan video call). Rincian kegiatan yang telah dilaksanakan sebagai berikut:

a. Survey pendahuluan tentang rencana kegiatan pengabdian masyarakat kepada Pengurus Koperasi Toko Kelontong dan Bagian Ekonomi Kecamatan Rungkut secara daring.

b. Mengidentifikasi permasalahan yang dihadapi anggota koperasi toko kelontong secara daring.

c. Melakukan pelatihan sesuai permasalahan yang dihadapi para anggota koperasi toko kelontong oleh Dosen STIESIA Surabaya secara offline.

d. Melakukan pendampingan secara daring melalui media whatsapp group dan video call. 
Pelatihan dan Pendampingan Kiat Meningkatkan Omzet Penjualan dan Pencatatan Transaksi Keuangan Pada Koperasi

Kegiatan pengabdian masyarakat ini dilaksanakan pada hari Selasa tanggal 15 Desember 2020 pada pukul 09.30 - 12.15 WIB. Kegiatan dilaksanakan di aula Kantor Kecamatan Rungkut Kota Surabaya. Kegiatan pendampingan dilaksanakan selama 3 hari, yaitu pada tanggal 23-24 Desember 2020 serta 06 Januari 2021 pada pukul 09.00 - 11.30 WIB. Kegiatan pendampingan dilaksanakan secara daring. Peserta kegiatan pengabdian ini adalah anggota Koperasi Toko Kelontong Rungkut Makmur Sejahtera Kecamatan Rungkut Surabaya.

\section{Materi Pelatihan}

\section{Kiat Meningkatkan Omzet Penjualan Toko Kelontong}

Narasumber: Wininatin Khamimah, S.E., M.Si.

\section{Gambaran toko kelontong dan minimarket di Indonesia}

- Ada 50 juta toko kelontong di Indonesia, tersebar dari Sabang sampai Merauke.

- Data menunjukkan ada 43.826 minimarket pada 2017 tumbuh 3,2 persen tiap tahun. Berarti ada sekitar 1.000 minimarket baru tiap tahun.

- Jumlah minimarket Indonesia terbesar di Asia Tenggara [Laporan Nielsen's What's Next for South East Asia].

- Pandemi Covid19 berdampak pada hampir semua bidang usaha, termasuk usaha retail/eceran.

- Selain kena imbas PandemiCovid 19, toko kelontong juga harus bersaing dengan minimarket yang terus bertambah dan merambah ke perkampungan.

\section{Cara Meningkatkan Omset Toko Kelontong}

- Melakukan Riset

- Menentukan Kebutuhan Pelanggan

- Membuat Keunikan Tersendiri

- Fokus. Fokus pada barang apa saja yang biasa dibeli dan barang paling banyak dicari.

- Pelayanan Terbaik.

- Serba Ada. Tidak menyetok barang yang jarang dibeli terlalu banyak, tapi tetap sediakan dalam jumlah terbatas.

- Harga. Bandingkan dengan harga barang yang sama di toko kelontong lain.

- Berteman dengan toko lain untuk saling melengkapi dan kerjasama.

- Antar Jemput. Ini layanan yang amat disukai pembeli. 
- Perhatikan Agen Tempat Anda Mendapatkan Barang. Melakukan ekspedisi ke berbagai agen untuk mencari agen dengan kualitas barang terbaik dan harga tetap dapat bersaing.

- Promosi. Orang-orang menyukai potongan harga dan promosi.

- Pemasaran online.Gunakan media social; whatsapp, facebook, instagram dan lainlain.

- Konsisten dan Disiplin. Meskipun di awal-awal usaha pendapatan kecil dan bahkan tidak sesuai keinginan, namun tetap memperbaiki kualitas.

\section{Materi Pencatatan Transaksi Keuangan}

Narasumber: Nenny Syahrenny, S.E., M.Ak., Ak., CA, ACPA, CTA
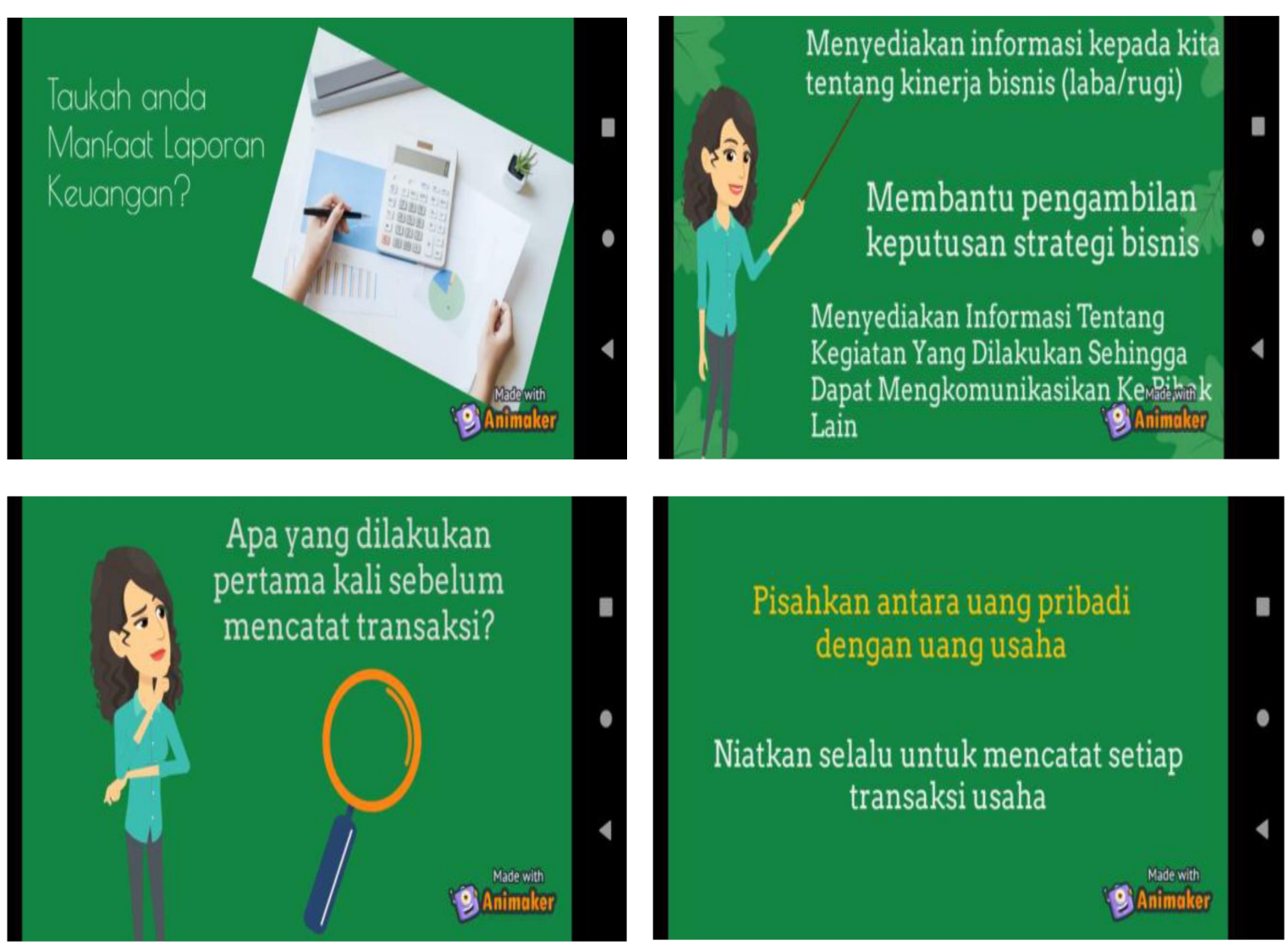

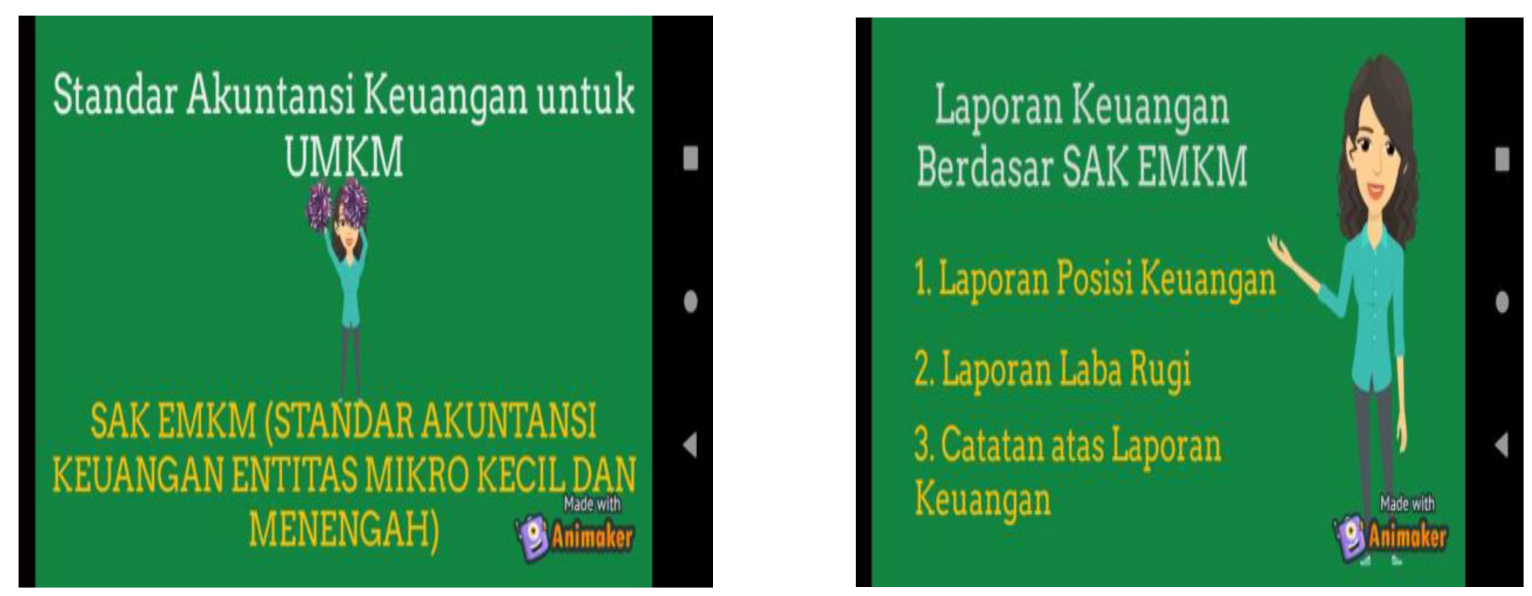

Gambar 1. Materi Pencatatan Transaksi Keuangan

\section{HASIL DAN PEMBAHASAN}

Secara umum program pengabdian kepada masyarakat dirancang Sekolah Tinggi Ilmu Ekonomi Indonesia (STIESIA) Surabaya untuk memberikan kontribusi nyata bagi masyarakat dalam mengembangkan kesejahteraan dan kemajuan masyarakat Indonesia. Pengabdian kepada masyarakat ini merupakan kegiatan yang bertujuan membantu anggota koperasi toko kelontong di Kecamatan Rungkut Kota Surabaya dalam menghadapi beberapa kendala usahanya, khususnya di era new normal. Rincian hasil pelaksanaan kegiatan pengabdian kepada masyarakat mulai awal hingga akhir pelaksanaan kegiatan dijabarkan pada Tabel 3.

Tabel 1. Hasil Pelaksanaan Kegiatan Pengabdian

\begin{tabular}{|c|c|}
\hline Keg & Keterangan \\
\hline $\begin{array}{l}\text { Koordinasi Tim } \\
\text { PkM \& Pihak } \\
\text { Kecamatan }\end{array}$ & $\begin{array}{l}\text { - Kegiatan PkM ini diawali dengan koordinasi tim PkM (4 dosen \& } 2 \\
\text { mahasiswa). } \\
\text { - Setelah itu, perwakilan tim PkM (Wininatin Khamimah, S.E., M.Si.) } \\
\text { melakukan koordinasi dengan pihak kecamatan terkait rencana PkM } \\
\text { sehubungan dengan adanya permintaan pihak kecamatan kepada } \\
\text { STIESIA untuk menjadi narasumber pelatihan pada anggota koperasi } \\
\text { toko kelontong Kecamatan Rungkut. }\end{array}$ \\
\hline $\begin{array}{l}\text { Ident } \\
\text { Perm }\end{array}$ & $\begin{array}{l}\text { - Mengadakan survey terhadap mitra PkM dan mengidentifikasi } \\
\text { permasalahan yang dihadapi mitra PkM. }\end{array}$ \\
\hline $\begin{array}{l}\text { Koor } \\
\text { dan T }\end{array}$ & $\begin{array}{l}\text { - Melakukan koordinasi terkait teknis pelaksanaan PkM offline dan online } \\
\text { yang akan dilakukan. }\end{array}$ \\
\hline Persiapan Materi & ateri untuk pelatihan. \\
\hline Persic & $\begin{array}{l}\text { - Dosen melakukan koordinasi terkait kesiapan pelaksanaan PkM. } \\
\text { - Memberi pengarahan kepada mahasiswa untuk mencatat dan } \\
\text { mendokumentasi pelaksanaan PkM offline dan online. }\end{array}$ \\
\hline Persiapan mitra & $\begin{array}{l}\text { - Persiapan dengan mitra dilakukan melalui daring, yaitu membentuk grup } \\
\text { whatsapp dan melakukan video call dengan mitra/peserta pelatihan, } \\
\text { untuk memastikan bahwa peserta sudah memahami teknis pelaksanaan } \\
\text { PkM offline dan online/daring yang akan dilakukan. }\end{array}$ \\
\hline Persiapan Teknis & - Teknis pelaksanaan Pelatihan offline sebagai berikut: \\
\hline
\end{tabular}




\begin{tabular}{|c|c|}
\hline Pelaksanaan & $\begin{array}{l}\text { Mengundang para anggota koperasi (berjumlah 12 orang) untuk } \\
\text { menghadiri kegiatan pelatihan di kantor Kecamatan Rungkut. } \\
\text { - Teknis pelaksanaan Pendampingan online/daring sebagai berikut: } \\
\text { a) Membagi peserta video call menjadi } 4 \text { grup, masing-masing berisi } 4 \\
\text { anggota (sebab ada peserta yang belum update whatsapp-nya } \\
\text { sehingga hanya bisa video call maksimal } 4 \text { orang). VC } 1 \text { : Bu Wini, } \\
\text { Bu Kartika, Bu Sutik, Bu Didik, Grup VC 2: Bu Wini, Bu Ana, Pak } \\
\text { Hardi. VC 3: Pak Arma, Pak Arifin, Bu Titik. VC 4: Bu Nenny, Bu } \\
\text { Tegowati, Bu Kartika, Bu Didik \& Pak Arifin. } \\
\text { b) Saling bertukar grup untuk mendapatkan pendampingan yang } \\
\text { berbeda (sesuai materi pelatihan) dari masing-masing dosen. }\end{array}$ \\
\hline $\begin{array}{l}\text { Pelaksanaan PkM } \\
\text { (Pelatihan \& } \\
\text { Pendampingan) }\end{array}$ & $\begin{array}{l}\text { - Pelaksanaan pelatihan dilakukan secara offline/tatap muka langsung. } \\
\text { Peserta yang hadir diminta mengisi daftar hadir terlebih dahulu oleh } \\
\text { panitia, kemudian peserta diberi fotocopy materi dan konsumsi. Setelah } \\
\text { semua peserta hadir, kegiatan pelatihan dimulai dan diakhiri dengan } \\
\text { tanya jawab seputar materi pelatihan. Dalam kegiatan pelatihan ini juga } \\
\text { disampaikan mengenai kegiatan pendampingan yang akan dilakukan. } \\
\text { Materi pelatihan yang diberikan ada dua, yaitu: } \\
\text { 1. Kiat meningkatkan omzet penjualan di era new normal. } \\
\text { 2. Pencatatan transaksi keuangan. } \\
\text { - Pelaksanaan pendampingan melalui grup whatsapp \& video call. } \\
\text { Pertama, tim PkM dan mitra menyepakati hari dan jam untuk dilakukan } \\
\text { kegiatan pendampingan melalui grup whatsapp, kemudian dilakukan } \\
\text { pendampingan melalui video call. }\end{array}$ \\
\hline Penutupan & $\begin{array}{l}\text { - Pembubaran whatsapp grup PkM dengan memberikan kesimpulan serta } \\
\text { pesan dan kesan oleh peserta dan tim PkM. } \\
\text { - Untuk selanjutnya mitra tetap diperbolehkan mengirim pesan melalui } \\
\text { whatsapp pribadi jika ada permasalahan yang ingin didiskusikan. }\end{array}$ \\
\hline
\end{tabular}

Pada kegiatan pelatihan, peserta mendapatkan materi tentang meningkatkan omzet penjualan toko kelontong di era new normal dan pencatatan transaksi keuangan pada koperasi toko kelontong. Peserta antusias bertanya terutama pada materi pencatatan transaksi keuangan sebab peserta merasa ingin menguasai lebih mendalam terkait materi ini. Sebagian peserta juga menyampaikan bahwa mereka masih malas melakukan pembukuan karena merasa bahwa usaha milik sendiri dan bukan usaha utama (hanya sampingan). Peserta juga minta diadakan pelatihan dan pendampingan lanjutan dalam pembukuan menggunakan barcode seperti di minimarket modern (seperti Alfamart dan Indomart).

Sebagian peserta ada yang berniat untuk mencatat dengan baik transaksi keuangannya agar mengetahui keluar atau masuknya keuangan. Bahkan sudah membeli software, namun masih butuh pendampingan karena belum bisa pembukuan. Sudah ada pula aplikasi lewat handphone (scan barcode) yang digunakan, namun belum bisa digunakan untuk pembukuan sesuai standar. Dalam kegiatan pelatihan ini peserta/mitra juga menyampaikan harapannya supaya bisa dipermudah untuk membuat laporan 
Pelatihan dan Pendampingan Kiat Meningkatkan Omzet Penjualan dan Pencatatan Transaksi Keuangan Pada Koperasi

keuangan terkait laporan pajak (ada aplikasi pembukuan yang praktis dan mudah digunakan).

Sedangkan pada kegiatan pendampingan PkM (secara daring) para peserta diberi pendampingan lebih mendalam terkait pelatihan yang sudah dilakukan. Saat pendampingan ini para peserta/pemilik usaha toko kelontong menyampaikan berbagai permasalahan terkait usaha toko kelontong mereka. Selain memang dampak pandemi COVID-19 (misal sekolah tutup sehingga omzet penjualan toko kelontong mitra yang berada di dekat sekolah menurun), permasalahn lain yang dihadapi peserta antara lain:

a. Semakin bermunculan toko kelontong dan minimarket di sekitar usaha toko kelontong mitra sehingga persaingan semakin ketat. Hal ini karena harga dan jenis produk/barangbarang yang ditawarkan relatif sama antar toko. Para pemilik usaha toko kelontong ini tidak mampu menjual harga yang lebih rendah lagi. Sebab jika ingin menjual dengan harga rendah mereka harus membeli dalam jumlah banyak dan hal ini belum bisa dilakukan karena kendala modal usaha.

b. Munculnya pesaing dadakan yang menjual sembako di depan rumah atau di pinggir jalan juga menjadi permasalahan dalam usaha toko kelontong.

c. Ada pemilik toko kelontong yang juga membuat minuman sinom tetapi belum memiliki kemasan kekinian. Kemasan sekarang masih seperti produk lain.

d. Sebagian pemilik usaha toko kelontong sudah menerapkan pesan antar barang ke pelanggan, namun ada sebagian lagi yang belum bisa melayani pesan antar karena kendala SDM.

e. Sebagian pemilik usaha toko kelontong belum ada kesadaran dari dalam diri untuk melakukan pencatatan barang dan transaksi keuangan secara berkelanjutan, bahkan ada yang belum melakukan pencatatan transaksi keuangan sama sekali.

f. Sudah punya alat untuk scan barcode, tetapi kadang tidak semua pembelian dilakukan melalui alat scan ini karena beberapa konsumen tidak mau menunggu/kurang sabar.

g. Sudah menggunakan aplikasi Ayokasir dan memakai alat barcode sehingga pembelian dan penjualan sudah tercatat otomatis (Bu kartika). Informasi yang diperoleh dengan adanya aplikasi tersebut adalah laba dan nilai stok persediaan. Namun, belum bisa menampilkan Laporan Keuangan sesuai dengan SAK EMKM. Kedepannya menginginkan penyusunan LK yang bisa langsung jadi dari aplikasi karena pemilik merangkap menjadi admin.

h. Tidak ada pembukuan (Bu Didik). Pernah membuat pembukuan sederhana dengan arus kas masuk dan keluar. Pembukuan tersebut dibantu oleh mahasiswa KKN dari UINSA 
Surabaya. Kemudian karena tidak ada waktu sehingga tidak mencatat lagi. Kedepannya ingin ada kesempatan mencatat dan ingin membeli alat barcode sehingga otomatis mengetahui stok persediaan.

Dari permasalahan-permasalahan ini, tim STIESIA telah memberikan pelatihan berupa kiat meningkatkan omzet penjualan di era new normal dan pencatatan transaksi keuangan. Pemilik usaha toko kelontong juga telah menerapkan beberapa cara untuk mengatasi permasalahnnya, antara lain:

a) Melakukan pembukuan dan barcode.

b) Melakukan kerjasama dengan warung kopi/angkringan berupa pembayaran di belakang.

c) Program promo Jum'at barokah dengan menjual barang sesuai harga pokok.

d) Menyediakan layanan pesan antar.

e) Bergabung dengan aplikasi GrabMart sehingga konsumen bisa membeli melalui aplikasi ini.

f) Memasang brosur virtual/flyer untuk alat promosi di medsos seperti WA, IG, Facebook dan lain-lain yang dibuatkan Tim PkM STIESIA Surabaya.
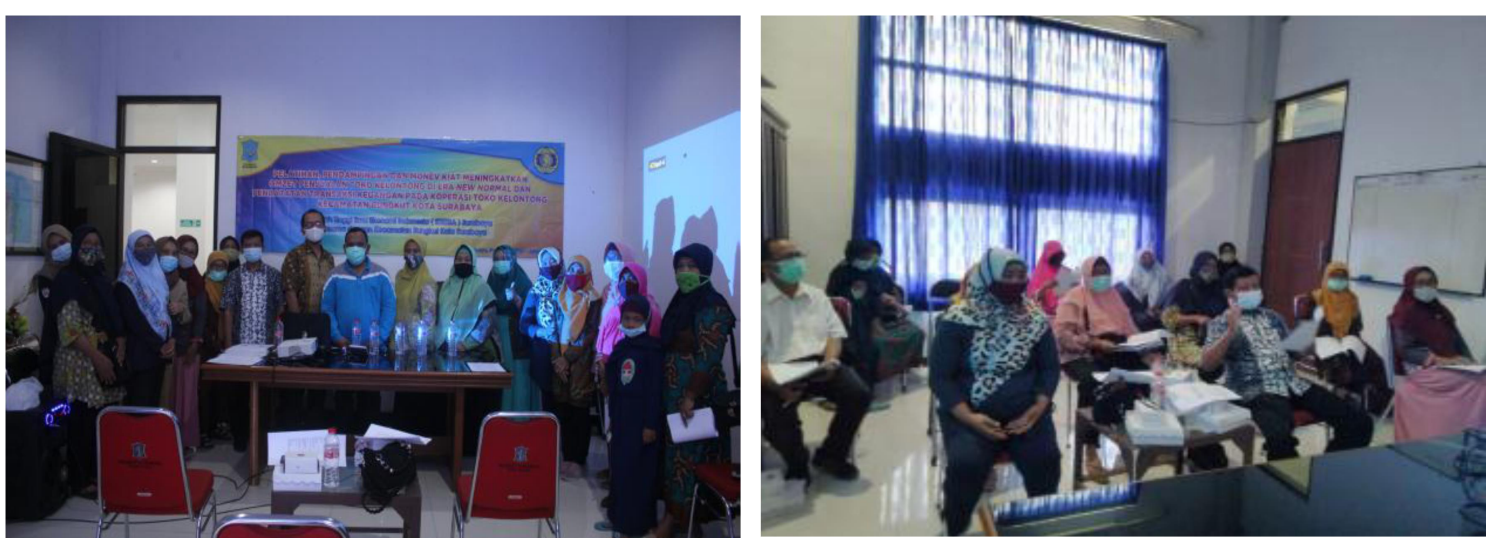

Gambar 2. Foto Kegiatan pelatihan secara tatap muka 
Pelatihan dan Pendampingan Kiat Meningkatkan Omzet Penjualan dan Pencatatan Transaksi Keuangan Pada Koperasi
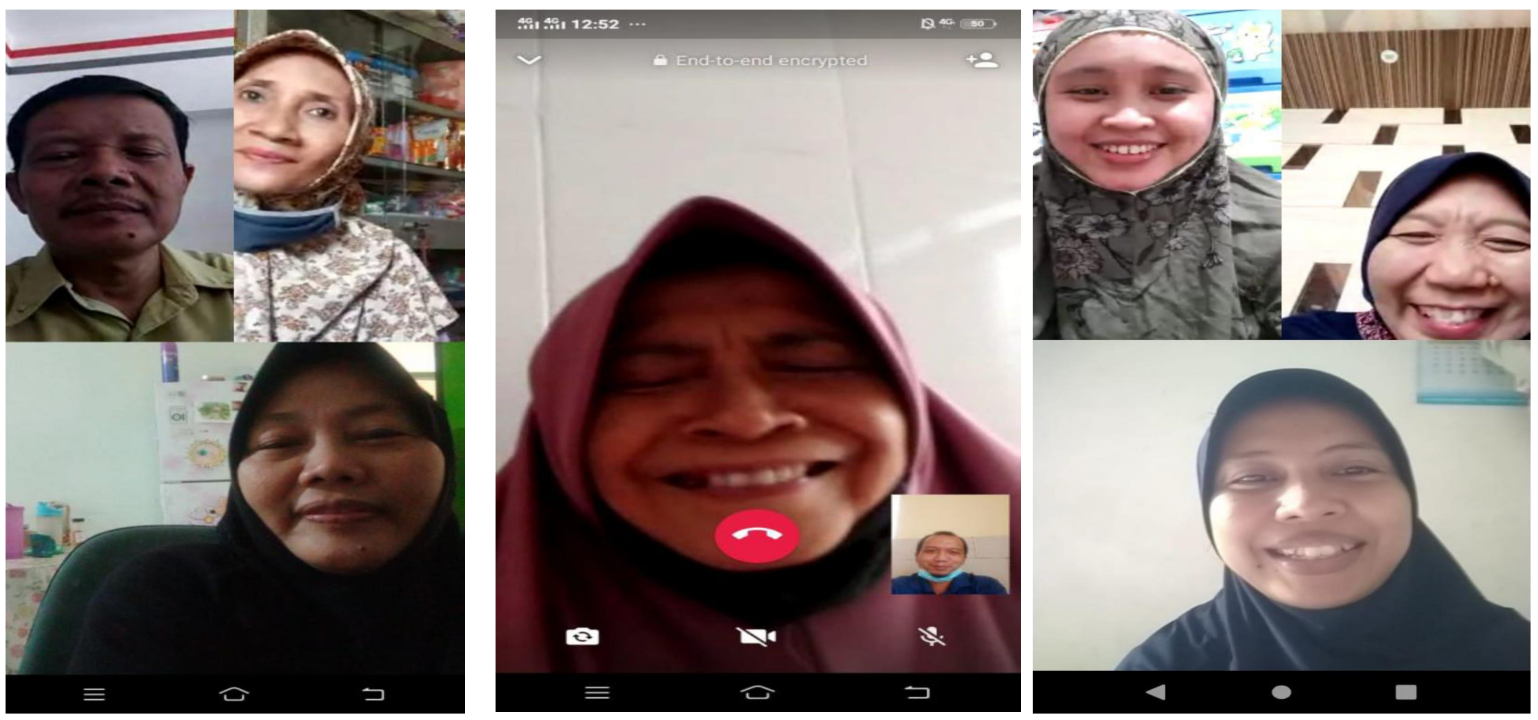

Gambar 3. Foto Kegiatan pendampingan secara daring

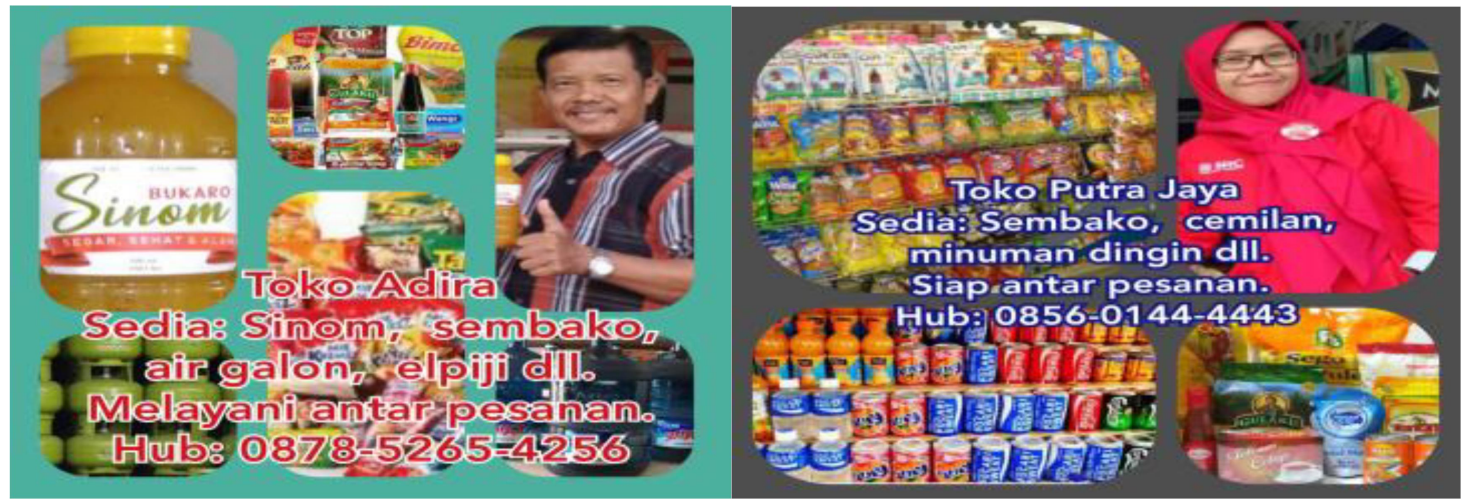

Gambar 4. Contoh brosur virtual/flyer sebagai media promosi online untuk peserta oleh Tim PkM STIESIA Surabaya

\section{KESIMPULAN DAN SARAN}

Kegiatan pengabdian kepada masyarakat bagi anggota koperasi toko kelontong telah berjalan dengan baik dan sesuai rencana. Kegiatan ini memberikan manfaat bagi para anggota koperasi toko kelontong. Setelah pelatihan dan pendampingan mereka mengetahui dan akan menerapkan kiat meningkatkan omzet penjualan toko kelontong. Sedangkan untuk materi pencatatan transaksi keuangan banyak anggota koperasi toko kelontong yang belum mampu menerapkan.

Berdasarkan fakta di atas, maka perlu dilakukan pengabdian kepada masyarakat lanjutan. Kegiatan pengabdian kepada masyarakat yang diterapkan melalui pelatihan dan pendampingan ini dapat memberi manfaat kepada para peserta, maka selanjutnya menyarankan: 
1. Perlu kesinambungan kegiatan dan evaluasi setelah kegiatan pengabdian kepada masyarakat ini dilakukan. Sebab dalam kegiatan ini ditemukan permasalahan lain yang membutuhkan pelatihan dan pendampingan (antara lain pembukuan dan pencatatan keuangan menggunakan aplikasi) supaya para pemilik usaha toko kelontong lebih maju. Sehingga dapat berkontribusi dalam pengembangan koperasi toko kelontong di Indonesia.

2. Bekerja sama dengan pihak-pihak yang kompeten dalam membuat aplikasi pembukuan yang praktis dan mudah digunakan.

3. Mengadakan edukasi serupa kepada jenis usaha lainnya.

\section{UCAPAN TERIMA KASIH}

Pelatihan ini dapat berjalan dengan lancar karena peran dan dukungan dari beberapa pihak. Kami menyampaikan terima kasih kepada:

1. Ketua Sekolah Tinggi Ilmu Ekonomi Indonesia (STIESIA) Surabaya yang memfasilitasi pelaksanaan kegiatan Pengabdian kepada Masyarakat sebagai salah satu kewajiban dosen dalam pemenuhan Tridharma Perguruan Tinggi.

2. Kepala Lembaga Penelitian dan Pengabdian kepada Masyarakat (LPPM) yang telah mendampingi dan mengkoordinatori kegiatan pengabdian dengan beberapa UMKM di Surabaya.

3. Bapak Drs. Yanu Mardianto, M.Si. (Bapak Camat Rungkut) beserta staf, yang berkenan menyediakan tempat kegiatan pengabdian, serta menyampaikan masukanmasukan dan informasi tentang kondisi sosial ekonomi di Kecamatan Rungkut.

4. Bapak Suhardi, Ketua Koperasi Toko Kelontong Kecamatan Rungkut yang bersedia menjadi mitra dalam pelaksanaan kegiatan ini.

5. Seluruh peserta yang merupakan para anggota Koperasi Toko Kelontong yang telah bersedia mengikuti kegiatan ini.

\section{DAFTAR PUSTAKA}

Andarsari, Pipit Rosita dan Justita Dura, (2018), Implementasi Pencatatan Keuangan Pada Usaha Kecil Dan Menengah (Studi Pada Sentra Industri Kripik Tempe Sanan Di Kota Malang), Jurnal JIBEKA Volume 12 No 1,: 59 - 64.

Ikatan Akuntan Indonesia, (2016) Standar Akuntansi Keuangan Entitas Mikro, Kecil dan Menengah, Penerbit Ikatan Akuntan Indonesia, Jakarta,

Khamimah, Wininatin, (2020). Pelatihan, Pendampingan dan Monev Etika Bisnis Saat Pandemi Covid-19 di Koperasi Toko Kelontong Rungkut Surabaya. Dalam; Prosiding Seminar Nasional Ke-6, 3 November 2020. Implementasi Bela Negara, 
Pelatihan dan Pendampingan Kiat Meningkatkan Omzet Penjualan dan Pencatatan Transaksi Keuangan Pada Koperasi

Melalui Pengabdian Kepada Masyarakat, LPPM UPN "Veteran” Yogyakarta, 157164.

Rizal, Rusma, Romidon Hidayat, Ica Handika, (2017), Analisis Bauran Pemasaran Terhadap Omzet Penjualan Pada PT. Gaudi Dwi Laras Cabang Palembang, Jurnal Adminika Volume 3. No. 2, Juli-Desember:, 78-93.

R, Muhammad Rais, (2019), Analisis Sistem Pencatatan Akuntansi Pada Usaha Mikro Kecil Dan Menengah Kota Baubau, Jurnal Ilmiah Akuntansi Manajemen Volume 2 Nomor 1 - April, 60-71.

http;//dinkopum.surabaya.go.id, Koperasi Toko Kelontong Di Surabaya, 30 Septermber 2019

https;//www.republika.co.id, 885 Koperasi Toko Kelontong Di Surabaya Dapat Pendampingan, 6 Pebruari 2021.

https://blog.mokapos.com/tips-sukses-usaha-toko-kelontong, 5 Tips Sukses Usaha Toko Kelontong di Era Global, 9 September 2019, diakses pada 5 Nopember 2020

https://dosenekonomi.com/bisnis/tips-bisnis/cara-eningkatkan-omset-toko-kelontong, $\quad 10$ Cara Meningkatkan Omset Toko Kelontong Terampuh, diakses pada 5 Nopember 2020

www.cnbcindonesia.com, Ketika Warung Kelontong Jadi Buruan Bank, 10 Pebruari 2020, diakses pada 13 Desember 2020

https://marketers.com, Jumlah minimarket Indonesia Terbanyak di Asia Tenggara, 31 Mei 2019, Diakses pada 13 Desember 2020 